\title{
Peningkatan Kemampuan Menentukan Nilai Tempat Bilangan Melalui Media Tangga Pintar Bagi Anak Kesulitan Belajar Berhitung Kelas IV di SDN 06 Batang Anai
}

\author{
Yola Ananda ${ }^{1}$, Damri $^{2}$ \\ 1, 2 Program Studi Pendidikan Luar Biasa, Fakultas Ilmu Pendidikan, Universitas Negeri Padang, \\ Jl. Prof. Dr. Hamka Air Tawar Barat Kec. Padang Utara, Padang, Indonesia \\ plbyolaananda@gmail.com
}

\begin{abstract}
This research originated from the discovery of a child with difficulty counting in grade IV at SDN 06 Batang Anai. $\mathrm{He}$ is not able to answer the practice questions correctly and can only guess, this is the reason he does not understand the basic concept of counting, especially in determining the place value of numbers. This study aims to improve the ability to determine the place value of numbers using smart ladder media. This study used the single subject research (SSR) method with the A-B-A design, the baseline activity (A1) was held four times, the intervention activity (B) was carried out seven meetings and the second baseline activity (A2) was held five times. Data obtained through observation, interviews, documentation and action tests, then analyzed using a visual graph in the form of a percentage. The results obtained in the baseline activity (A1) in determining the place values for numbers obtained percentages of $33 \%, 44 \%, 44 \%$ and $44 \%$, to determine the value of numbers obtained percentages of $22 \%, 33 \%, 33 \%$ and $33 \%$. The results of the intervention activity (B) to determine the place value of the numbers obtained percentages of $44 \%, 55 \%, 44 \%, 66 \%, 77 \%, 77 \%$ and $77 \%$, to determine the value of numbers obtained the percentage of $44 \%, 55 \%, 66 \%, 66 \%, 88 \%, 88 \%$, and $88 \%$. The results of the second baseline activity (A2) in determining the place values for numbers obtained percentages of $66 \%, 77 \%, 88 \%, 88 \%$, and $88 \%$, to determine the value of numbers, the percentage of $55 \%, 77 \%, 88 \%, 88 \%$ and $88 \%$ was obtained. . Based on the results of the research above, it is clear that the use of smart ladder media in determining the place value of numbers is effectively used for students who have difficulty learning to count.
\end{abstract}

Keywords: Number place value, smart ladder media, difficulty learning to count

\begin{abstract}
Abstrak
Penelitian ini berawal dari ditemukan seorang anak kesulitan berhitung kelas IV di SDN 06 Batang Anai. Ia tidak mampu menjawab soal latihan dengan benar hanya bisa menerka-nerka, inilah penyebab ia belum memahami konsep dasar berhitung terutama dalam menentukan nilai tempat bilangan. Penelitian ini bertujuan meningkatkan kemampuan menentukan nilai tempat bilangan dengan menggunakan media tangga pintar. Penelitian ini menggunakan metode single subject research (SSR) dengan desain A-B-A, kegiatan baseline (A1) dilaksanakan empat kali pertemuan, kegiatan intervensi (B) dilaksanakan tujuh kali pertemuan dan kegiatan baseline kedua (A2) dilaksanakan lima kali pertemuan. Data diperoleh melalui observasi, wawancara, dokumentasi dan tes perbuatan, selanjutnya dianalisis menggunakan visual grafik dalam bentuk persentase. Hasil yang diperoleh pada kegiatan baseline (A1) dalam menentukan nilai tempat bilangan diperoleh persentase $33 \%, 44 \%$, $44 \%$ dan $44 \%$, untuk menentukan nilai angka bilangan diperoleh persentase 22\%, 33\%, 33\% dan 33\%. Hasil kegiatan intervensi (B) untuk menentukan nilai tempat bilangan diperoleh persentase 44\%, 55\%, 44\%, 66\%, 77\%, 77\% dan 77\%, untuk menentukan nilai angka diperoleh persentase 44\%, 55\%, 66\%, 66\%, 88\%, 88\%, dan 88\%. Hasil kegiatan baseline kedua (A2) dalam menentukam nilai tempat bilangan diperoleh persentase $66 \%, 77 \%, 88 \%, 88 \%$, dan $88 \%$, untuk menentukan nilai angka diperoleh persentase 55\%, 77\%, 88\%, 88\% dan $88 \%$. Berdasarkan hasil penelitian diatas jelas bahwa penggunaan media tangga pintar dalam menentukan nilai tempat bilangan efektif digunakan untuk siswa kesulitan belajar berhitung.
\end{abstract}

Kata kunci: Nilai tempat bilangan, media tangga pintar, kesulitan belajar berhitung

Copyright (c) 2021 Yola Ananda, Damri

Corresponding author: Yola Ananda

Email Address: plbyolaananda@ gmail.com (Jl. Prof. Dr. Hamka Air Tawar Barat Kec. Padang Utara, Padang)

Received 24 Maret 2021, Accepted 02 April 2021, Published 23 April 2021

\section{PENDAHULUAN}

Pendidikan pada dasarnya hakikatnya adalah proses pembelajaran untuk membantu siswa keluar dari ketidaktahuan dan kemiskinan, oleh karena itu layanan pendidikan yang berkualitas diperlukan untuk membantu siswa terhindar dari kesulitan belajar (Ardisal \& Damri, 2013). Melalui proses 
pendidikan dan pembelajaran, siswa dapat mengembangkan potensi dan ilmunya. Salah satu siswa yang seharusnya mendapatkan pendidikan ini adalah ABK. ABK adalah siswa yang memiliki ciri khas tersendiri dibandingkan anak normal seusianya. Perbedaannya terletak pada kondisi fisik, emosi dan mental yang berada di bawah atau diatas rata-rata anak normal (Damri, 2019).

Ada beberapa kategori ABK yaitu anak kesulitan belajar AKB. Siswa kesulitan belajar adalah mereka yang memiliki keterbatasan pada perkembangan akademik sebagai akibatnya mereka perlu diberikan pengajaran secara spesifik (Efendi, 2019) Salah satu siswa dengan kesulitan belajar adalah siswa kesulitan belajar berhitung atau mengalami diskalkulia.

Kesulitan belajar berhitung adalah kesulitan memahami simbol untuk berpikir, mencatat, dan mengungkapkan gagasan tentang kuantitas. Hal tersebut dibenarkan oleh beberapa ahli antara lain (1) (Kasmawati,2018); (2) (Suryani, 2010); (3) (Mulyadi, 2010), mereka setuju bahwa pada dasarnya diskalkulia atau kesulitan belajar berhitung adalah kesulitan menyelesaikan sebuah kasus terkait hitunghitungan karena terdapat masalah pada saraf pusatnya. Pada kehidupan sehari-hari dalam kondisi belajar berhitung, kegiatan yang lazim diguankan ialahkegiatan yang berkaitan dalam menggunakan uang dan waktu, mengukur, jumlah, operasi hitung dan sebagainya.

Siswa dengan masalah belajar matematika merasa tanpa harapan karena akan sulit bagi mereka untuk belajar, apabila jika diberikan pelajaran baru yang akan ada hubungan dengan pelajaran sebelumnya (Marlina, 2019). Salah satu kesulitan yang biasa di alami oleh siswa saat berhitung adalah materi nilai tempat (Jarmita, 2015). Pendapat ini dibenarkan oleh (Efda, 2013) yang menegaskan bahwa nilai tempat adalah nilai atau posisi bilangan dalam suatu lambang bilangan.

Pelajaran nilai tempat ini diberikan untuk membantu anak menyelesaikan latihan seperti operasi hitung bilangan (Sari \& Fatmawati, 2019). Penyataan diatas dibenarkan oleh (Efda, 2013) yang menegaskan bahwa nilai tempat adalah nilai atau posisi suatu bilangan dalam suatu lambang bilangan tergantung di mana bilangan itu ada dalam suatu bilangan. Berkaitan dengan pendapat sebelumnya (Jarmita, 2015) mengungkapkan bahwa siswa akan kesulitan dalam mengerjakan latihan yang menggunakan bilangan basis sepuluh hal ini dikarenakan siswa belum mengerti akan konsep nilai tempat.

Terjadinya kondisi diatas menyebabkan kegagalan siswa dalam mempelajari latihan berhitung. Dimana pelajaran berhitung adalah pelajaran utama yang bisa membantu dalam pemecahan kasus harian dan juga diperlukan di tingkat pendidikan yang lebih tinggi (Marlina, 2019). Kesulitan siswa harus diatasi dengan membantu mereka mencari solusi agar nantinya di kelas matematika tidak ada masalah yang lebih komplek yang berakibat pada kemampuan akademik yang buruk seperti melakukan operasi bilangan (Savitri et al., 2019). Untuk mengatasi kesalahan tersebut, peneliti memakai alat peraga untuk memberikan pembelajaran.

Media pembelajaran merupakan alat yang menawarkan/mendeskripsikan pendapat belajar (Ardisal \& Damri, 2013). Sejalan dengan pendapat ahli diatas (Arsyad, 2014) mengungkapkan bahwa “ Media Pembelajaran merupakan segala sesuatu yang dipakai dalam mengungkapkan pelajaran pada proses 
pembelajaran sebagai akibatnya bisa menarik minat anak dalam belajar”. Selain itu, (Rostina, 2013) juga menyatakan bahwa "Media Pembelajaran menjadi pemberi informasi pada aktivitas pengajaran". Senada dengan pernyataan diatas, (Indriana, 2011) juga menyampaikan bahwa "Media Pengajaran merupakan pemberian pembelajaran menggunakan alat komunikasi untuk mengungkapkan pelajaran secara konkret.

Media yang digunakan dapat membantu anak anak menyelesaikan masalah mereka. Berbagai cara yang dapat membantu anak mengatasi masalah seperti; (1) Penggunaan media kantong bilangan terbukti efektif dalam meningkatkan kemampuan menentukan nilai tempat bilangan (Yuni, 2019); (2) Media papan bilangan, edia ini sesuai diberikan dalam materi nilai tempat (Febrician, R., 2019)serta (3) Media tangga pintar.

Media tangga pintar ini sudah banyak diteliti oleh peneliti terdahulu antara lain oleh(Putra, R, E., \& Clara, 2020); (Maulidiyah, Nurul Khikmah, 2019); (Yuli, 2018), media ini dirasa layak dan efektif digunakan karena dapat meningkatkan hasil belajar baik pada pembelajaran bobot satuan maupun operasi hitung bilangan yang melibatkan penjumlahan dan pengurangan. Jadi, dari beberapa penelitian di atas dapat disimpulkan bahwa media inicocok digunakan untuk meningkatkan hasil belajar siswa pada materi nilai tempat.

Media tangga adalah alat tiga dimensi yang dirancang sedemikian rupa seperti tangga (Yuli, 2018). Media ini dibuat dengan kode warna tertentu sesuai dengan nilai tempat bilangan serta dilengkapi dengan kartu angka dan kartu nilai angka yang juga diberi warna sesuai nilai tempat bilangan. Media ini memiliki kelebihan antara lain dapat meningkatkan keaktifan siswa yang membuat siswa berperan aktif dalam pembelajaran, menarik perhatian dan bersikap konkrit. Berdasarkan pernyataan di atas, peneliti memutuskan memakan media tangga ini dalam membantu anak memahami materi tentang nilai tempat bagi siswa kesulitan belajar berhitung. Berikut dibawah ini dilampirkan gambar media tangga pintar, kartu angka dan kartu nilai angka:

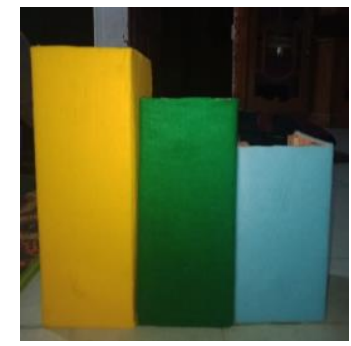

Gambar 1 Tangga Pintar

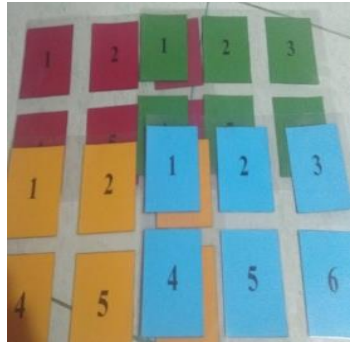

Gambar 2 Kartu Angka

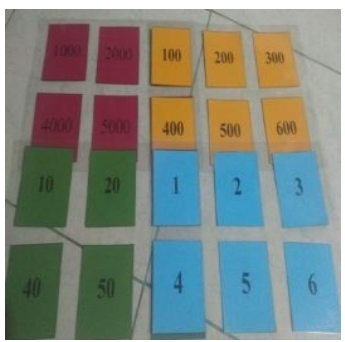

Gambar 3 Kartu Nilai Angka

Berdasarkan studi pendahuluan yang diperoleh dari hasil identifikasi awal dan observasi kondisi anak di kelas dari guru kelas, siswa mengalami kesulitan berhitung terutama dalam menentukan nilai tempat bilangan. Fakta diatas mendorong peneliti untuk membantu anak pada tahap intervensi dengan menggunakan media tangga pintar untuk meningkatkan kemampuan menentukan nilai tempat bilangan terutama pada bilangan tiga digit angka (satuan, puluhan, dan ratusan). 


\section{METODE}

\section{Jenis penelitian}

Jenis penelitian yang digunakan adalah penelitian eksperimen dengan SSR. Tujuan mencari efektifitas pengobatan yang terkendali (Sugiyono, 2014). Desain penelitian ini adalah A1-B-A2. Penelitian ini dilakukan dalam enam belas kali pertemuan, dengan 4 kali pengamatan untuk kegiatan $\left(A_{1}\right), 7$ kali pengamatan untuk kegiatan $(B)$ dan lima pengamatan untuk kegiatan terhadap perilaku anak tanpa adanya perlakuan $\left(\mathrm{A}_{2}\right)$.

\section{Subjek dan Setting}

Subjek yang peneliti ambil dalam penelitian ini adalah anak kesulitan belajar berhitung di kelas IV yang bersekolah di SD Negeri 06 Batang Anai. Penelitian ini dilakukan yang beralamat di Kayu Kapur, Kecamatan Batang Anai, Kabupaten Padang Pariaman. Penelitian ini dilakukan pada waktu diluar jam efektif saat daring di rumah dengan memperhatikan protokol kesehatan (dengan memakai face shield, hand sanitizier).

\section{Teknik pengumpulan dan Teknik Analisis Data}

Data penelitian ini menggunakan teknik pengumpulan penelitian ini teknik pengumpulan data yang peneliti gunakan ialah melalui kegiatan pengamatan/observasi, wawancara dan tes berupa perilaku. Penggunaan teknik observasi peneliti dilakukan dengan mengamati kegiatan berhitung. Sedangkan wawancara peneliti lakukan dengan adanya kerjasama dengan guru untuk perolehan informasi terhadap siswa dalam belajar serta melihat hasil lembar kerja siswa telah diperiksa oleh guru yang mendapati kendala bahwa selama mengerjakan latihan yang diberikan siswa mendapat hasil yang rendah terutama dalam hal hitung-hitungan dan selama ini siswa juga menjawab dengan hanya menerka-nerka namun siswa tersebut tidak tahu dengan konsep yang dipelajari.

Teknik pengumpulan data yang digunakan ialah berbentuk tes, peneliti memberikan kegiatan dalam tes berhitung. Tes perilaku ini peneliti lakukan dengan meminta siswa mengerjakan soal dan kemudian melihat hasil kerja siswa. Adapun teknik analisis data yang peneliti gunakan ialah menggunakan penilaian berupa persentase terhadap kemampuan siswa dalam menentukan nilai tempat bilangan dan analisis data dijabarkan melalui visual grafik agar lebih jelas.

\section{HASIL PENELITIAN}

Penelitian ini dilakukan di SDN 06 Batang Anai dimana mereka belajar berhitung. Penelitian ini dilaksanakan dalam enam belas kali pertemuan, dengan menggunakan desain ABA, kegiatan (A1) dilakukan dalam mengamati kemampuan awal anak, kegiatan (B) yaitu kegiatan memberikan intervensi, dan kondisi baseline kedua (A2) yaitu kondisi setelah diberikan perlakuan. Hasil penelitian ini menunjukkan bahwa proses pembelajaran untuk menentukan nilai tempat bilangan menggunakan media tangga pintar mengalami peningkatan. Untuk lebih jelasnya bisat dilihat pada keterangan dan analisis penelitian dalam grafik dibawah ini: 


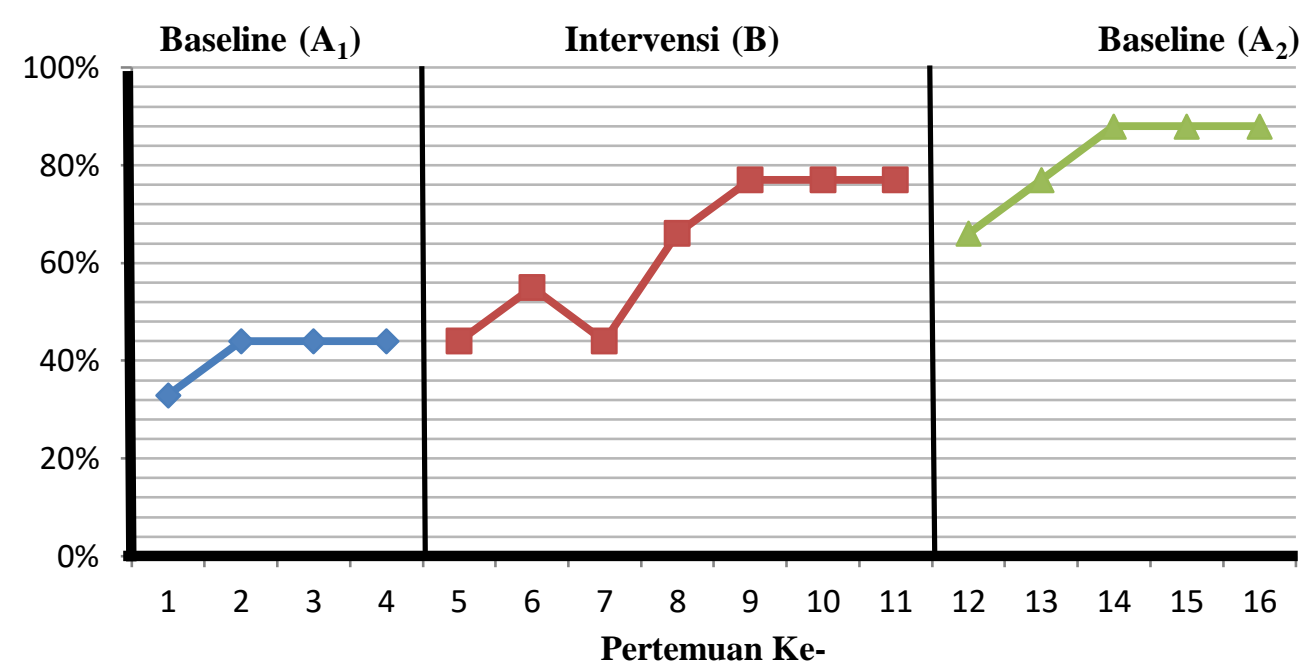

Grafik 1. Kemampuan Menentukan Nilai Tempat Bilangan Pada Kondisi A1, B Dan A2
Baseline $\left(A_{1}\right)$
Intervensi (B)
Baseline $\left(\mathbf{A}_{2}\right)$

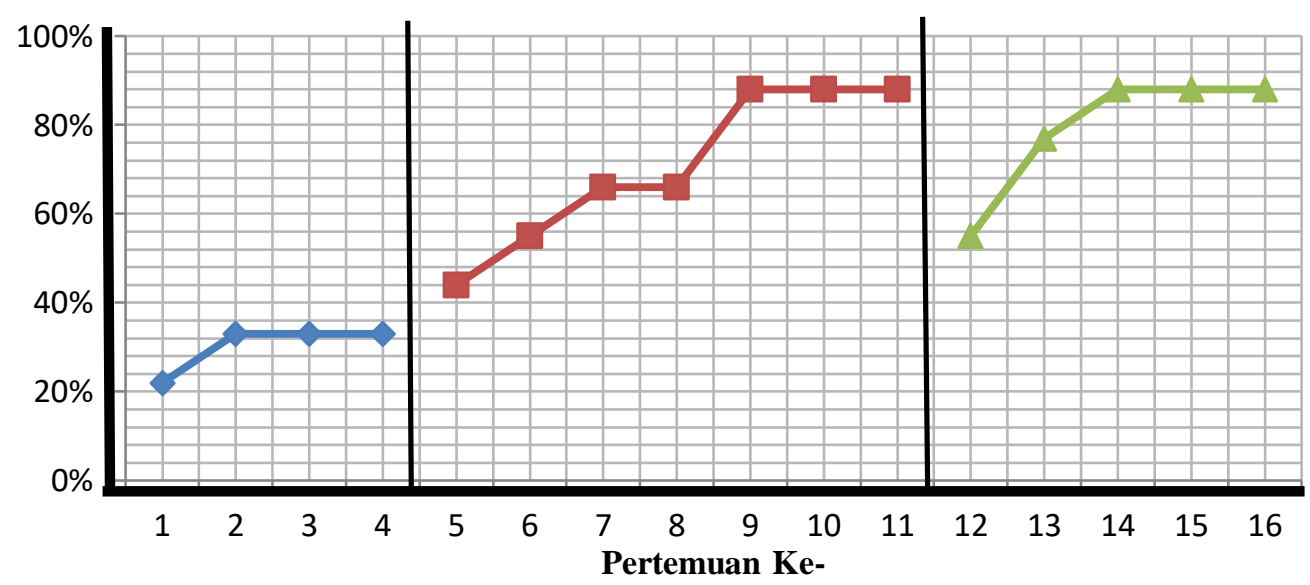

Grafik 2. Kemampuan Menentukan Nilai Angka Bilangan Pada Kondisi A1, B Dan A2

Dari paparan grafik diatas didapat hasilnya bahwa pada kegiatan (A1) mendapat persentase 33\% pada pertemuan pertama, pertemuan kedua sampai keempat sebesar $44 \%$. Pada kemampuan menentukan nilai angka suatu bilangan pertemuan pertama diperoleh persentase sebesar $22 \%$ dan pertemuan kedua sampai ketiga sebesar 33\%. Pengamatan dihentikan pada pertemuan keempat karena data yang diperoleh stabil dan dilanjutkan pada kegiatan B.

Pada kondisi intervensi kemampuan anak dalam menentukan nilai tempat bilangan tersebut meningkat dibandingkan kondisi baseline (A1). Pada kemampuan menentukan nilai tempat bilangan pertemuan kelima mendapatkan persentase sebesar $44 \%$, pertemuan keenam sebesar 55\%, pertemuan ketujuh sebesar $44 \%$, pertemuan kedelapan sebesar 66\%, pertemuan kesembilan sampai pertemuan kesebelas sebesar 77\%. Pada kemampuan menentukan nilai angka suatu bilangan pertemuan kelima sampai pertemuan ketujuh diperoleh persentase sebesar $44 \%$, pertemuan kedelapan sebesar 55\%, 
pertemuan ketujuh sampai pertemuan kedelapan mendapat persentase sebesar $66 \%$, pertemuan kesembilan sampai pertemuan kesebelas sebesar $88 \%$. \%. Pengamatan dihentikan pada pertemuan kesebelas karena data yang diperoleh stabil dan dilanjutkan pada kegiatan A2.

Pada kegiatan A2 dalam menentukan nilai tempat bilangan, terjadi peningkatan ditunjukkan dengan persentase yang diperoleh pada pertemuan kedua $66 \%$, pertemuan ketiga belas menerima persentase sebesar 77\%, pertemuan keempat belas sampai pertemuan keenam belas didapat persentase sebesar $88 \%$. Selanjutnya pada kemampuan menentukan nilai angka suatu bilangan pertemuan kedua belas menerima persentase sebesar 55\%, pertemuan ketiga belas sebesar 77\%, pertemuan ke 14 hingga pertemuan ke 16 sebesar $88 \%$. Pengamatan dihentikan pada pertemuan ke 16 dikarekan data yang diperoleh stabil dan tidak berubah.

Untuk melihat perubahan dan peningkatan setelah diberikan perlakukan atau intervensi pada penggunaan media tangga pintar terhadap kemampuan menentukan nilai tempat bilangan, berikut peneliti gambarkan dalam bentuk grafik sebagai berikut:

Baseline ( $\left.\mathbf{A}_{1}\right)$

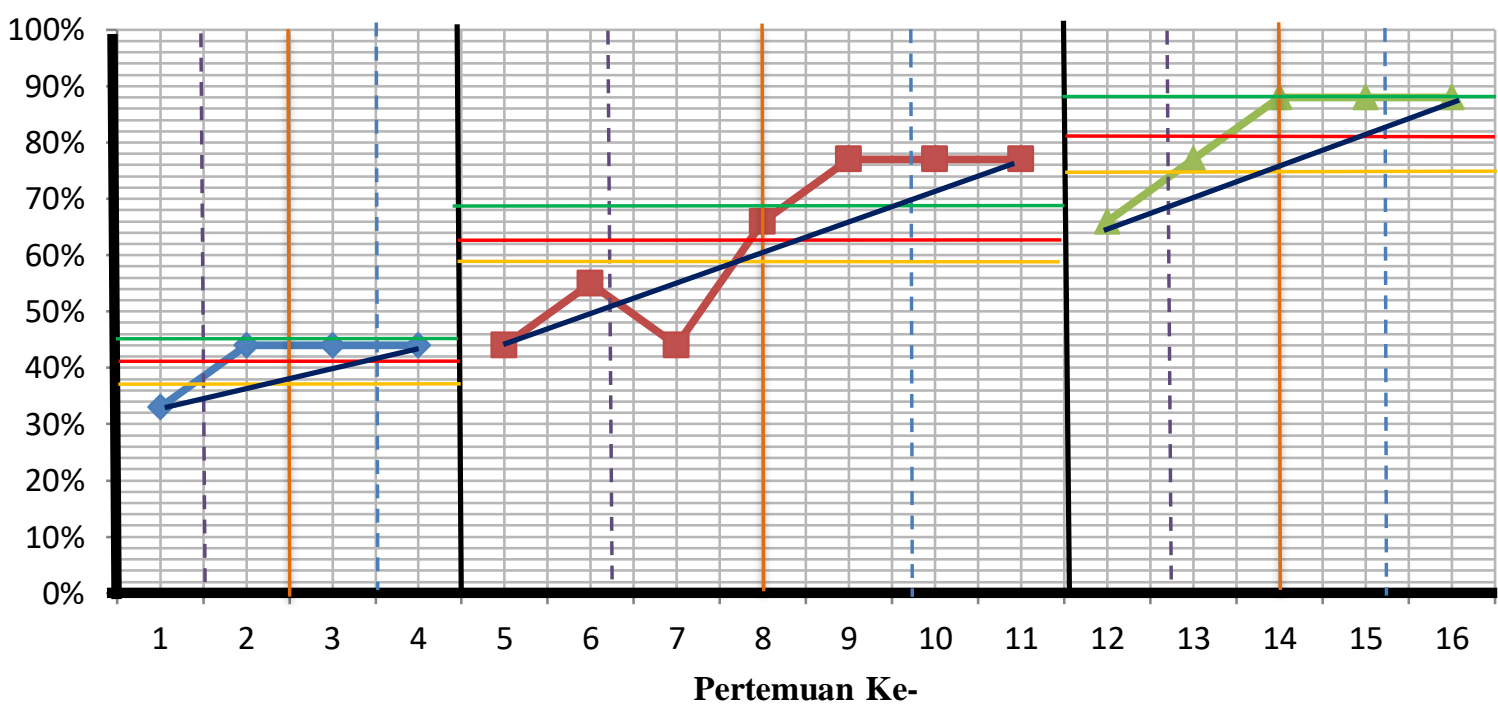

Grafik 3. Hasil Analisis Kemampuan Menentukan Nilai Tempat Bilangan Setelah diberikan Perlakuan Menggunakan Media Tangga Pintar 


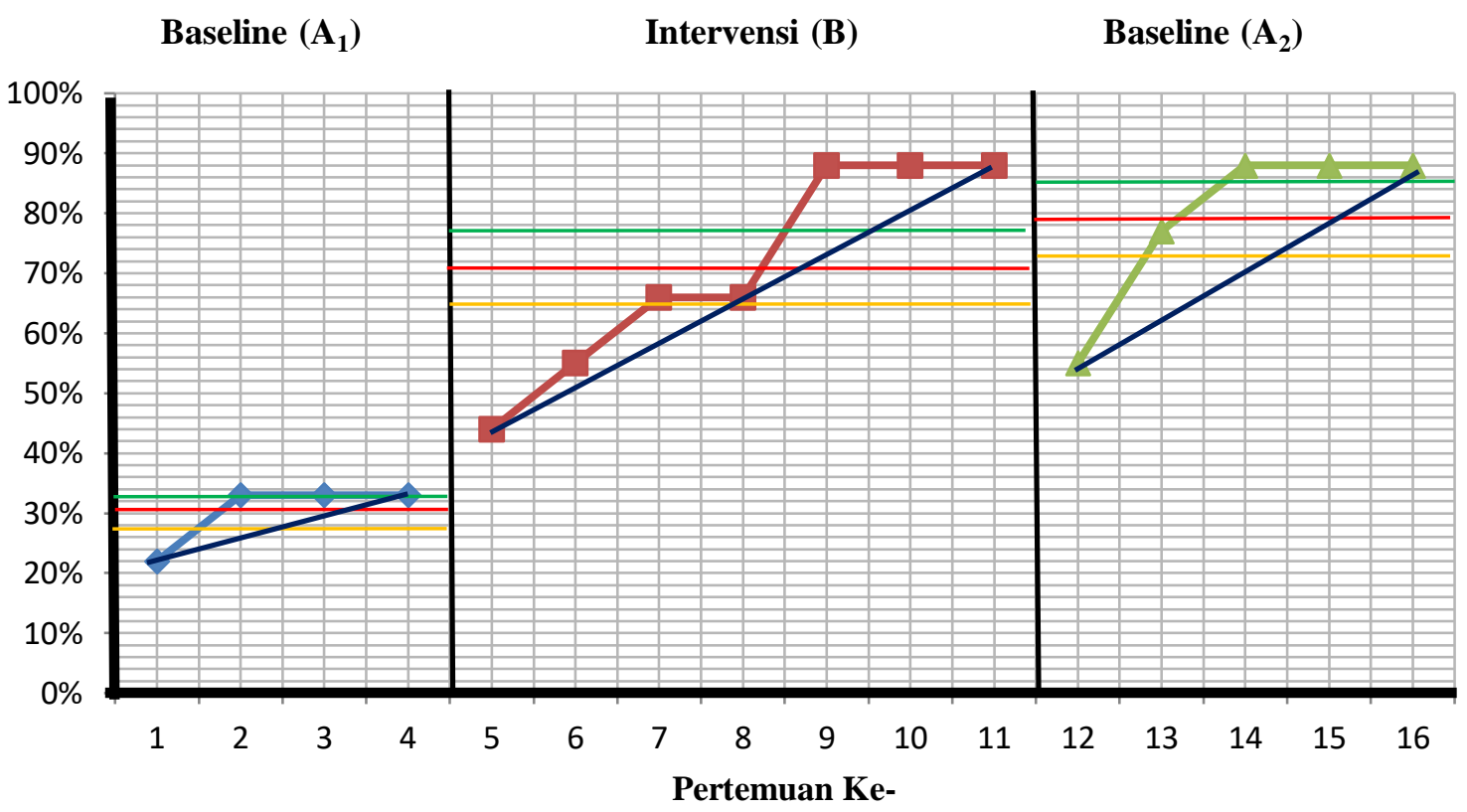

Grafik 4. Hasil Analisis Kemampuan Menentukan Nilai Angka Bilangan Setelah diberikan Perlakuan Menggunakan Media Tangga Pintar

Berdasarkan grafik 3 dan 4 di atas hasil analisis data menunjukkan bahwa intervensi dengan menggunakan media tangga pintar efektif dalam meningkatkan kemampuan menentukan nilai tempat bilangan pada dua kelompok kemampuan pada anak kesulitan belajar berihitung. Media tangga pintar merupakan media tiga dimensi yang dibuat sedemikian rupa menyerupai tangga (Yuli, 2018). Media ini dibuat dengan kode warna tertentu sesuai dengan nilai tempat bilangan serta dilengkapi dengan kartu angka dan kartu nilai angka yang juga diberi warna sesuai dengan nilai tempat bilangan masing-masing.

Dari hasil pengamatan yang dilakukan selama enam belas kali pertemuan dengan masingmasing dalam 3 kegiatan, yaitu kegiatan A1 dilakukan 4 kali pengamatan, kegiatan B dilakukan dalam 7 kali pertemuan dan kegiatan A2 dilakukan selama lima kali pertemuan. Dalam melaksanakan penelitian peneliti memberi 18 butir soal yang menilai jawaban yang di jawab benar oleh anak. Hasil yang didapat dari latihan yang dikerjakan anak ketika menggunakan media tangga pintar terbukti memberi pengaruh positif dan efektif.

Kegiatan A1 hasil menunjukkan hasil yang stabil dan meningkat dalam menentukan nilai tempat bilanga. Pada kondisi intervensi (B) dengan media tangga pintar diperoleh hasil yang meningkat dan stabil dalam menentukan nilai tempat bilangan tersebut. Pada kegiatan A2 menunjukkan peningkatan dan hasil yang tidak berubah dalam menentukan nilai tempat bilangan. Pemberian intervensi menggunakan media tangga pintar dalam menentukan nilai tempat bilangan membantu siswa untuk meningkatkan kemampuan nya dalam menentukan nilai tempat suatu bilangan. Salah satu bentuk intervensi adalah penggunaan media tangga pintar. Penggunaan media tangga pintar telah banyak dipelajari oleh peneliti sebelumnya (Putra, R, E., \& Clara, 2020) (Maulidiyah, Nurul Khikmah, 2019); 
(Yuli, 2018) mereka berpendapat bahwa media ini sesuai dan efektif karena dapat meningkatkan hasil belajar anak, baik dalam pembelajaran satuan berat, maupun dalam operasi aritmatika yang melibatkani penjumlahan dan pengurangan.

\section{KESIMPULAN}

Penelitian yang telah dilakukan di SDN 06 Batang Anai terhadap penggunaan media tangga pintar pada siswa kesulitan belajar berhitung dalam kemampuan menentukan nilai tempat bilangan disimpulkan dapat meningkat. Analisis keseluruhan kondisi terjadi peningkatan terhadap kemampuan siswa dalam menentukan nilai tempat bilangan bagi siswa kesulitan belajar berhitung melalui pemberian intervensi atau obat menggunakan media tangga pintar ini. Hasil pengumpulan data menunjukkan bahwa media tangga pintar ini dapat memberikan hasil yang baik dalam menentukan nilai tempat bilangan pada siswa dengan keterbatasan dalam berhitung di kelas IV di Sekolah Dasar Negeri 06 Batang Anai Padang Pariaman Sumatera Barat.

\section{UCAPAN TERIMA KASIH}

Terimakasih penulis ucapkan kepada Bapak/Ibu Kepala Sekolah, Guru, dan siswa di SDN 06 Batang Anai yang sudah bersedia memberikan izin untuk melaksanakan penelitian ini, dan membantu dalam melaksanakan kegiatan penelitian ini. Terimakasih kepada Bapak/Ibu Dosen prodi Pendidikan Luar Biasa yang sudah membimbing penulis selama ini.

\section{REFERENSI}

Ardisal, A., \& Damri, D. (2013). PELAKSANAAN PEMBELAJARAN SISWA BERKEBUTUHAN KHUSUS DI SMK NEGERI. 4 PADANG. Pedagogi: Jurnal Ilmu Pendidikan, 13(1), 105-109. Arsyad. (2014). Media Pembelajaran. Jakarta: Rajawali Press.

Damri. (2019). Panduan Pembelajaran Inklusi Di Sekolah Menengah Pertama. Cv.Irdh.

Efda, Y. (2013). Upaya Meningkatkan Kemampuan Nilai Tempat Pada Pembelajaran Matematika Menggunakan Media Maze Bagi Anak Tunagrahita Ringan Kelas DIV. Jurnal Pendidikan Khusus, 1.

Efendi, J. (2019). Efektifitas Alat Terigonal Pencil dalam Peningkatan Menulis pada Anak Kesulitan Belajar di SDN 20 Kalumbuk Padang. Pendidikan Khusus, 4, 152.

Febrician, R., \& M. (2019). Meningkatkan Kemampuan Menentukan Nilai Tempat Bilangan Melalui Media Papan Bilangan Bagi Anak Berkesulitan Belajar. 7, 97-102.

Indriana, D. (2011). Ragam Alat Bantu Media Pembelajaran. Yogyakarta: DIVA.Press.

Jarmita, Ni. (2015). Kesulitan Pemahaman Konsep Matematis Siswa dalam Pembelajaran Matematika di Kelas Awal Sekolah Dasar. Journal Pendidikan, 1-16.

Kasmawati, \& I. (2018). Pendekatan Realistic Mathematics Education (Rme) untuk Meningkatkan Kemampuan Operasi Hitung Anak Diskalkulia. Jurnal Penelitian Pendidikan Kebutuhan Khusus, 
6, 256-261.

Marlina. (2019). Asesmen Kesulitan Belajar. Prenadamedia Grup.

Maulidiyah, Nurul Khikmah, S. (2019). Operasi Hitung Sederhana dengan Media Tangga Pintar Anak Tunagrahita Hasil dan Pembahasan Hasil. 1, 96-99.

Mulyadi. (2010). Diagnosis Kesulitan Belajar dan Bimbingan Terhadap Kesulitan Belajar Khusus. Yogyakarta: Nuha Litera.

Putra, R, E., \& Clara, N. (2020). Matematika Dengan Metode Demonstrasi. 5, 568-575.

Rostina, S. (2013). Media Pembelajaran. Bandung: Alfabeta.

Sugiyono. (2014). Metode Penelitian Pendidkan. Bandung: Alfabeta.

Suryani, Y. E. (2010). Kesulitan Belajar. 7, 33-47.

Yuli, V. E. M. (2018). Pengembangan Media PembelajaranTangga Pintar Materi Penjumlahan dan Pengurangan Kelas I Sekolah Dasar. Jurnal Penelitian Ilmu Pendidikan, 11.

Yuni, A. D. (2019). Meningkatkan Kemampuan Menentukan Nilai Tempat Bilangan Melalui Media Kantong Bilangan bagi Siswa Berkesulitan Belajar di SDN 19 Air Tawar Barat. Jurnall Penelitian Pendidikan Kebutuhan Khusus, 7. 